\title{
Molecular identification of Mango, Mangifera indica L.var. totupura
}

\author{
Sankar Jagarlamudi ${ }^{1}$, Rosaiah G $^{2}$, Ravi Kumar Kurapati ${ }^{1}$ \& Rajasekhar \\ Pinnamaneni $^{3 *}$
}

${ }^{1}$ Institute of Biological Sciences, Vijayawada, Andhra Pradesh, India; ${ }^{2}$ Department of Botany, Acharya Nagarjuna University, Nagarjuna Nagar, Andhra Pradesh, India; ${ }^{3}$ Department of Biotechnology, Sreenidhi Institute of Science and Technology, Yamnampet, Ghatkesar, R.R.District, Andhra Pradesh, India; Rajasekhar Pinnamaneni - Email: pinnamaneniraj@gmail.com; *Corresponding author

Received September 20, 2010; Accepted January 10, 2011; Published February 15, 2011

\begin{abstract}
:
Mango (Mangifera indica) belonging to Anacardiaceae family is a fruit that grows in tropical regions. It is considered as the King of fruits. The present work was taken up to identify a tool in identifying the mango species at the molecular level. The chloroplast trnL-F region was amplified from extracted total genomic DNA using the polymerase chain reaction (PCR) and sequenced. Sequence of the dominant DGGE band revealed that Mangifera indica in tested leaves was Mangifera indica (100\% similarity to the ITS sequences of Mangifera indica). This sequence was deposited in NCBI with the accession no. GQ927757.
\end{abstract}

Key words: Mango, Mangifera indica, trnL-F.

Abbreviations: AFLP-Amplified fragment length polymorphism, cpDNA-Chloroplast DNA, DDGE-Denaturing gradient gel electrophoresis, DNADeoxyribo nucleic acid, EDTA-Ethylenediamine tetraacetic acid, HCl-Hydrochloric acid, ISSR-Inter simple sequence repeats, ITS- Internal transcribed spacer, MATAB-Methyl Ammonium Bromide, $\mathrm{Na}_{2} \mathrm{SO}_{3}$-Sodium sulphite, $\mathrm{NaCl}$-Sodium chloride, NCBI- National Centre for Biotechnology Information PCR-Polymerase chain reaction, PEG-Polyethylene glycol, RAPD-Randomly amplified polymorphic DNA, trnL-F-Transfer RNA genes start codontermination codon

\section{Background:}

Mango (Mangifera indica) is a fruit that grows in tropical regions belonging to Anacardiaceae Lindl., the cashew family which includes more than 700 species in 82 genera that are primarily distributed pantropically. Mangifera indica L. originated in a region including the north-eastern part of India (Assam), the western part of Myanmar, and Bangladesh. Mango was domesticated in this region and has been cultivated in India for 4000 years. Cultivation spread first to Malaysia and South-East Asia, supposedly expanded by Buddhist monks. Purseglove suggested that Phoenicians and Arabs spread the crop from India to East-Africa where it has been cultivated since the $10^{\text {th }}$ century. The global spread of mango outside its original centres of domestication probably did not occur until the beginning of the European voyages of the $15^{\text {th }}$ and $16^{\text {th }}$ centuries, when the Portuguese took the mango to West-Africa and from there to Brazil at the beginning of the $18^{\text {th }}$ century, and when the Spanish introduced polyembryonic mango types from The Philippines to Central America through the Pacific trading ports of Mexico and Panama.

A regional inventory of fruit genetic resources has recently been undertaken in the French West Indies (FWI). The objective is to conserve the FWI fruit variability in-situ and ex-situ, as well as to try local varieties under standard conditions. The project includes a genetic diversity study of collected material in comparison with the diversity observed in the germplasm bank maintained locally in Guadeloupe [1]

Different markers have been used to study mango diversity: RAPD markers in Florida [2], India [3], [4] Venezuela [5] and Brazil [6], AFLP [7], and ISSR [8], [9] Nevertheless, these molecular markers are dominant ISSN 0973-2063 (online) 0973-8894 (print) Bioinformation 5(10): 405-409 (2011) and they do not permit the differentiation of heterozygous from homozygous accessions.

The first co-dominant markers developed were isozymes [10], [11], [12] More recently three research groups chose to develop SSR markers [13], [14] including our own [15]. These molecular markers are co-dominant, specific and highly variable. These qualities make them highly suitable to study diversity in supposedly related populations or cultivars. The present work was taken up to identify a tool in identifying the mango species at the molecular level.

\section{Materials and Methodology:}

\section{Plant materials and DNA isolation:}

Fresh leaves of Mango, Mangifera indica L.var.totupura used in this study for DNA extraction were collected from Nuziveedu, Krishna District, Andhra Pradesh, India. Plant tissue was ground in one of the ways: by hand with a mortar and pestle or in tubes with sterile glass beads and sand placed in a tissue disruptor.

\section{DNA extraction:}

DNA was extracted from fresh young leaves using a MATAB (Methyl ammonium Bromide) protocol described by Risterucci et al., (2000) [16]. Fresh leaves were grounded to a fine powder in liquid nitrogen, and incubated for $30 \mathrm{~min}$ at $74^{\circ} \mathrm{C}$ with extraction buffer $(1.4 \mathrm{M} \mathrm{NaCl}, 100 \mathrm{mM}$ Tris $\mathrm{HCl} \mathrm{pH} 8.0,20 \mathrm{mM}$ EDTA, $10 \mathrm{mM} \mathrm{Na} \mathrm{SO}_{3}, 1 \%$ PEG 6000, $2 \%$ $\mathrm{MATAB}$ ). After being cooled to $20^{\circ} \mathrm{C}$, an equal volume of chloroformisoamyl alcohol $(24: 1 \mathrm{v} / \mathrm{v})$ was added, $20-\mu 1$ reaction mixtures followed by emulsification. The tube was then centrifuged at $10000 \mathrm{~g}$ for $20 \mathrm{~min}$ and 405 


\section{Bioinformation}

DNA was precipitated from the supernatant with cold isopropanol. DNA concentrations were estimated on a $0.8 \%$ agarose gel stained with ethidium bromide.

\section{DNA amplification and sequencing:}

The chloroplast trnL-F regions were amplified from extracted total genomic DNA using the polymerase chain reaction (PCR) method. The universal primers 1, 2, 3 and 4 (Helini Biomolecules, Chennai) of Taberlet et al., 1991[17] (Table 1 see Supplementary material) (Figure 1) were used to amplify trnL-F. Thermal cycling parameters were an initial denaturation of 2 minutes at $97^{\circ} \mathrm{C} ; 30$ cycles of $94^{\circ} \mathrm{C}$ for one minute, annealing at $48^{\circ} \mathrm{C}$ for two minutes, and elongation at $72^{\circ} \mathrm{C}$ for two minutes; followed by an elongation step of $72^{\circ} \mathrm{C}$ for 16 minutes.

\section{Eluting DNA from agarose gel fragments:}

Ethidium bromide stained agarose gel was visualized under a transilluminator. The fragment of interest was excised with a clean razor blade. After removing the excess liquid, the agarose fragment was placed in the spin column. The tube was centrifuged at $5500 \mathrm{rpm}$ for not more than 45 seconds for the elution of DNA. The eluent was checked by running on an agarose gel and observed on a transilluminator for the presence of ethidium bromide stained DNA. The eluted DNA was used directly in manipulation reactions. This DNA fraction was subjected for sequencing (Helini Biomolecules, Chennai).
Sequencing and Phylogenetic placement:

The eluted PCR product was directly sequenced using trnL-F specific primers at Ohmlina Centre for Molecular Research, Chennai. Sequencing reactions were carried out with ABI PRISM Dye Terminator Cycle Sequence Ready Reaction Kit (Applied Biosystems Inc., USA). The obtained sequence was compared to the sequences in GenBank using the BLAST algorithm [18] to search for close evolutionary relatives.

\section{GenBank accession numbers:}

The representative sequence of the Mangifera indica species was deposited in GenBank of National Centre for Biotechnology Information (NCBI).

\section{Results and Discussion:}

Collection of Plant material:

Fresh leaves of Mango, Mangifera indica L.var.totupura were collected from Nuziveedu, Krishna District, Andhra Pradesh, India were used in this study for DNA extraction.

\section{Amplification of DNA coding for trnL-F:}

The genomic DNA of the Mangifera indica was subjected for the isolation of the DNA coding for trnL-F (Figure 2) by using Polymerase chain reaction. The bands were cut and eluted and the DNA so obtained was subjected for sequencing.

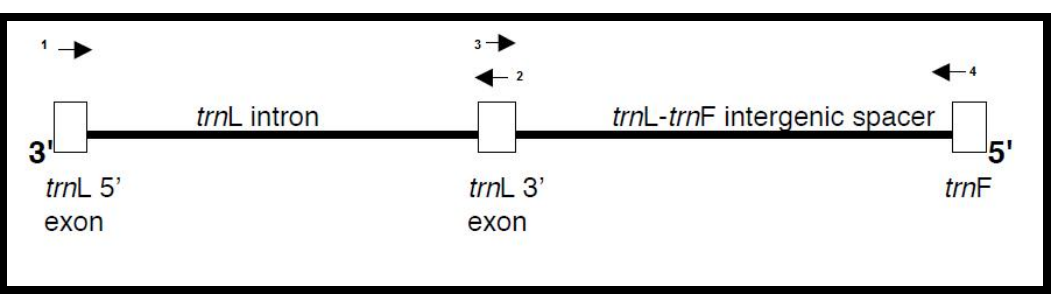

Figure 1: Approximate location of $t r n L-F$ primers used in this study

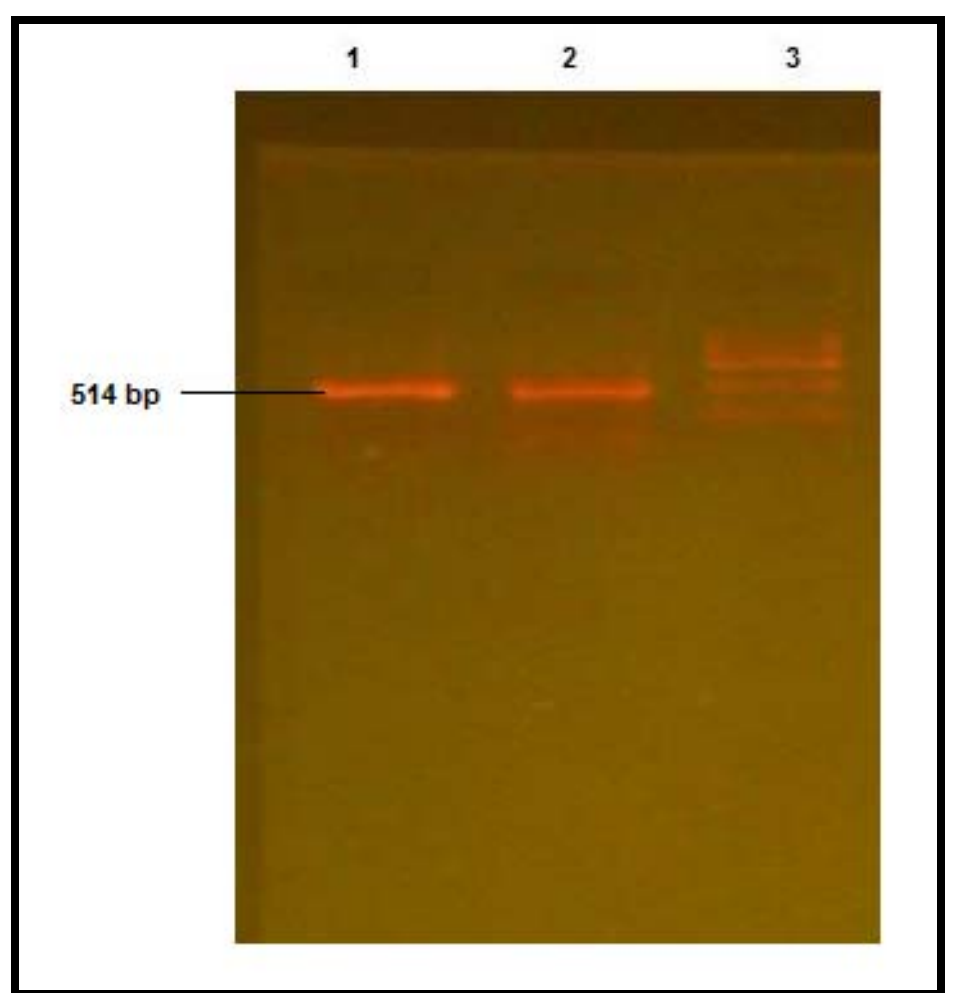

Figure 2: Agarose gel showing amplified trnL-F DNA of Mangifera indica L.var.totupura. Lane 1 and 2: Amplified DNA; Lane 3: 1 kb DNA Ladder 


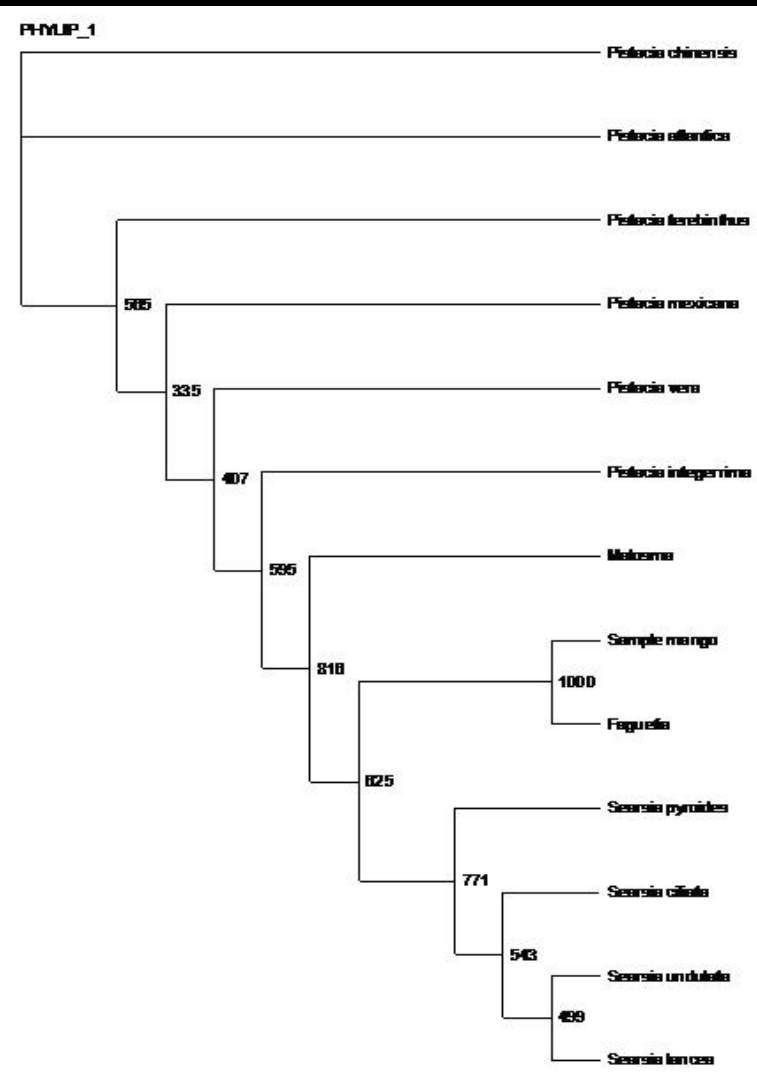

Figure 3: Phylogenetic affiliation of Mangifera indica based on trnL-F

Sequence analysis:

The sequence analysis demonstrated that all the corresponding bands on agarose gel belonged to Mangifera indica. Upon sequencing of the amplified DNA, the data obtained corresponds to 514 bases for Mangifera indica. The sequence so obtained was as follows.

CCAAATTGATTGAGCTTGGTATGGAAACCTACTAAGTGATAACT TTCAAATTCAGAGAAACCCTGGAATC

AAAAATGGGCAATCCTGAGCCAAATCCTATTTTACGAGAACAA

AAACAAACAAGGGGTCAGAACGGGAGA

AAAAAAGGATAGGTGCAGAGACTCAATGGAAGCTGTTCTAACA

AATGGAGTTGATTGCCTTTTTTGGGTA

AAGAAAGGAATTCTTCTATCGAATATCGAAAGGCCATAACGGA

TGAAGGATAAGCCTATATACACTATGT

ATAAGTAATGAAAAAATACACTATGTATACGTAATGAAAAAGG

ATCTCAAAAATGACGACCCGAATCCTT

TTTTGTTTTTCTTTTGAAGAACTAATTAATCAATCGGACGAGAAT

AAAGATAGAGTCCCATTCTACATGC

CAATATCAATACTGGCAACAATGAAATTTATAGTAAGAGGAAA

ATCCGTCGACTTTAGAAATCGTGAGGG

TTCAAGTCCTCCTATCCCCCAAAA

Phylogenetic affiliation of the Mangifera indica based on the ITS sequences:

Sequence of the dominant DGGE bands revealed that Mangifera indica in tested leaves was Mangifera indica $(100 \%$ similarity to the ITS sequences of Mangifera indica) with the accession no. GQ927757. This sequence can be found in NCBI Genome Databank. The phylogenetic tree was shown in Figure 3.

ISSN 0973-2063 (online) 0973-8894 (print)

Bioinformation 5(10): 405-409 (2011)
The dataset consisted of 514 characters $(100 \%)$ were parsimony informative. The matrix was easily manually aligned. Coding gaps as binary characters, missing data had no affect on the topology and very little affect on branch support. The $100 \%$ bootstrap consensus tree is shown in Figure 2. The trnL-F gene of mango was amplified and it was sequenced. The sequence was blasted againt $\mathrm{nr}$ database and the top hits were taken and aligned by multiple sequence alignment. The picture shows the phylogenetically related sequences. As our sequence is the first entry in genbank, there was no homologous sequence for mango. In future if mango sample was searched in database, our sequence will be the first hit. The topology is consistent with the maximum parsimony tree, which is more resolved within the Anacardiaceae clades.

The chloroplast DNA (cpDNA) trnT-F region in land plants consists of the transfer RNA genes $t r n T_{\text {ugu }}, t r n L_{\text {uаa }}$, and $t r n F_{\text {gaa }}$ arranged in tandem and separated by noncoding spacer regions. The region is positioned in the large single copy region, approximately $8 \mathrm{~kb}$ downstream of $r b c L$. The $\operatorname{trnL}$ gene of cyanobacteria and a number of chloroplast genomes, including that of all land plants, contains a group I intron positioned between the $U$ and the A of the UAA anticodon loop. This intron is inferred from phylogenetic analysis to have been present in the cyanobacterial ancestor of the plastid lineages of Rhodophyta, Chlorophyta, and Glaucocystophyta and to have been subsequently vertically transmitted [19].

The succession of conserved trn genes and the apparent absence of gene rearrangements in the trnT-F region made the design of plant universal primers possible [17]. As a consequence, the $t r n L-F$ region, comprising the trnL intron and trnL-F spacer, has become one of the most widely used 
chloroplast markers for phylogenetic analyses in plants [20]. The accumulation of an increasingly large number of sequences of the $\operatorname{trn}(T-) L$ $F$ region from a wide range of plants has allowed further study of structures, functions, and evolution in different orders of flowering plants [21], in basal angiosperms [22], in land plants [21], in bryophytes [23], and in Gnetales [24].

Sequences from the trnL-F region (excluding the trnT-L region and trnL 5 exon) have recently been used, in combination with those from further chloroplast markers $r b c L$ and $m a t K$, as a source of characters for phylogenetic reconstruction in the tropical flowering plant family Annonaceae Juss. These phylogenies have been used to answer questions about morphological character evolution [25], classification (Mols et al., 2004), biogeography [26] [27], and molecular dating [28]. These markers appeared to contain complementary phylogenetic signals, as is expected from different sequences sampled from the plastid genome [29], and were thus applied in combined analyses. The combined analyses yielded better resolved phylogenies, subject to higher levels of support, than those derived from individual markers.

\section{Conclusion:}

The above study can be utilized in identifying the Mango species directly by using any part of the tissue in live form or even from the fossil specimens. The gene sequences of $t r n L-F$ will be the same in any part of the plant because of the presence of chloroplast and its genome is same throughout. The sequence as reported in this present work is of Mangifera indica L.var. totupura. There was no sequence available in the database for mango till now and hence it can be exploited for the identification of mango species up to the level of varieties as the sequences will be more or less conserved with minor variations.

\section{References:}

[1] http://www.hort.purdue.edu/newcrop/morton/mango_ars.html

[2] RJ Schnell et al. Theoretical Applied Genetics (1995) 90: 269

[3] NVH Kumar \& P Narayanaswamy, Journal of Horticultural Science and Biotechnology (2001) 76(5): 529

[4] JL Karihaloo et al. Journal of Horticultural Science and Biotechnology (2003) 78(3): 285
[5] JA Lopez-Valenzeula et al. Hortscience (1997) 32(6): 1105

[6] VA Barbosa de Souza \& P Sarmanho da Costa Lima, Acta Horticulturae (2004) 645: 303

[7] W Eiadthong et al. J Am Soc Hortic Sci. (2000) 125(2): 160

[8] W Eiadthong et al. Scientia Horticulturae (1999) 82(1/2): 57

[9] A Gonzalez et al. Acta Horticultura. (2002) 575(1): 139

[10] C Degani et al. HortScience (1992) 27: 252

[11] GS Pascua et al. Philippine Journal of Crop Science, (1996) 21(Supplement 1): 10

[12] W Eiadthong et al. Thai Journal of Agricultural Science (1998) 31(4): 555

[13] C Honsho \& K Nishiyama, Molecular Ecology Notes (2005) 5: 152

[14] RJ Schnell et al. Molecular Ecology Notes (2005) 5: 625

[15] MF Duval et al. Molecular Ecology Notes (2005) 5(4): 824

[16] AM Risterucci et al. Theor Appl Genet (2000) 101: 948

[17] P Taberlet et al. Plant Molecular Biology (1991) 17: 1105 [PMID: 1932684]

[18] SF Altschul et al. Nucleic Acids Research (1997) 25: 3389 [PMID: 9254694]

[19] A Besendahl et al. Current Genetics (2000) 37: 12 [PMID: 10672439]

[20] D Quandt et al. Monographs in Systematic Botany (2004) 98: 13

[21] FT Bakker et al. Molecular Biology and Evolution (2000) 17: 1146 [PMID: 10991703]

[22] T Borsch et al. Journal of Evolutionary Biology (2003) 16: 558 [PMID: 14632220]

[23] D Quandt \& M Stech, Plant Biology (2004) 6: 545 [PMID: 15375725]

[24] H Won \& SS Renner, Journal of Molecular Evolution (2005) 61: 425 [PMID: 16155750]

[25] H Sauquet et al. Botanical Journal of the Linnean Society (2003) 142: 125

[26] JE Richardson et al. Philosophical Transactions of the Royal Society of London, B, Biological Sciences (2004) 359: 1495 [PMID: 15519968]

[27] MD Pirie et al. Journal of Biogeography (2006) 33: 31

[28] MD Pirie et al. Regnum Vegetabile (2005) 143: 149-174

[29] MW Chase \& AV Cox, Australian Systematic Botany (1998) 11: 215

Edited by B Lakshmi Citation: Sankar et al. Bioinformation 5(10): 405-409 (2011) License statement: This is an open-access article, which permits unrestricted use, distribution, and reproduction in any medium, for non-commercial purposes, provided the original author and source are credited. 


\section{Bioinformation Volume 5}

\section{Supplementary material:}

Table 1: Sequences of the trnL-F primers used in this study

\begin{tabular}{ll}
\hline Primer & 5'-3' Sequence \\
\hline 1 & CGAAATCGGTAGACGCTACG \\
2 & GGGGATAGAGGGACTTGAAC \\
3 & GGTTCAAGTCCCTCTATCCC \\
4 & ATTTGAACTGGTGACACGAG \\
\hline
\end{tabular}

